TAHKIM, Jurnal Peradaban dan Hukum Islam. Vol.2 No.2 (0ktober, 2019) | ISSN : $2597-7962$

\title{
SANKSI PELANGGARAN HAK CIPTA MENURUT HUKUM PIDANA ISLAM DAN HUKUM POSITIF DI INDONESIA
}

Yandi Maryandi

Fakultas Syariah Universitas Bandung

Yandi140985@gmail.com

\begin{abstract}
ABSTRAK
Secara hakiki segala yang diam dan bergerak di muka bumi baik daratan maupun lautan memang milik Allah. Kalau secara hakiki ini diterapkan dalam keseharian, kehidupan mendadak chaos karena siapa saja merasa khalifatullah. Namun, secara majazi hak milik Allah bisa diidhofahkan kepada siapa saja agar kehidupan jadi terang dan terus berjalan. Hak atas Kekayaan Intelektual (HKI) merupakan salah satu hak yang telah mendapatkan perlindungan secara hukum di Indonesia, ada beberapa peraturan perundang-undangan yang mengatur tentang hak-hak yang termasuk dalam ruang lingkup kekayan intelektual seperti hak cipta, hak paten, hak merek, hak rahasia dagang dan sebagainya. Yang perlu diketahui lebih mendalam adalah bagaimana hak cipta dalam perspektif hukum Pidana Islam karena Indonesia sebagai negara terbesar menganut agama Islam akan sangat mempengaruhi pemahaman dan kesadaran penduduk Indonesia akan pentingnya perlindungan terhadap hak atas kekayaan intelektual.
\end{abstract}

\section{Kata kunci: Hak Cipta, Hukum, Pidana Islam}

\begin{abstract}
Basically everything that is stationary and moves on the face of the earth, both land and sea, indeed belongs to God. If it is essentially applied in daily life, life suddenly chaos because anyone feels khalifatullah. However, by virtue of God's property can be transferred to anyone so that life will be bright and keep going. Intellectual Property Rights (IPR) is one of the rights that has been legally protected in Indonesia, there are several laws and regulations governing rights that are included in the scope of intellectual property such as copyright, patent rights, trademark rights, rights trade secrets and so on. What needs to be known more deeply is how copyright in the perspective of Islamic Criminal law because Indonesia as the largest country adheres to Islam will greatly affect the understanding and awareness of the Indonesian population on the importance of protecting intellectual property rights.
\end{abstract}

Keywords: Copyright, Law, Islamic Criminal 
TAHKIM, Jurnal Peradaban dan Hukum Islam. Vol.2 No.2 (0ktober, 2019) | ISSN : 2597-7962

\section{A. PENDAHULUAN}

Akhir-akhir ini di Indonesia marak sekali terjadi kasus pelanggaran terhadap hak cipta. Angka yang cukup fantastis ketika melihat kenyataan bahwasanya dari yang diketahui saja jumlahnya sudah cukup tinggi, belum lagi kasus-kasus kecil yang tidak mendapat perhatian khusus oleh pemerintah. Tentu jika dibiarkan hal ini dapat menimbulkan kerugian, tidak hanya bagi si pencipta dari karya tersebut saja, namun juga berdampak terhadap aspek sosial Negara bahkan aspek ekonomi Negara, dimana secara tidak langsung mempengaruhi indeks pemasukan pajak ke kas Negara.

Melihat dampak yang ditimbulkan cukup begitu membahayakan, tentu harus ada peranan pemerintah dalam menanggulangi kasus semacam ini, setidaknya dengan meminimalisir terjadinya hal ini. Salah satu yang bisa dilakukan adalah dengan penguatan praktik yuridis terhadap penerapan penyelesaian kasus yang ada.

Pada dasarnya hak cipta di gunakan untuk melindungi suatu karya ciptaan dalam bentuk ilmu pengetahuan, seni maupun sastra untuk mengurangi pembajakan pada karya ciptaannya. Hak cipta dapat dialihkan kepada pihak lain guna untuk mengumumkan atau memperbanyak ciptaan atas izin pencipta.

Pandangan islam terhadap hak cipta ada di Dalam Al-Qur'an di jelaskan pada Q.S AlBaqara ayat 188 Yang artinya: "dan janganlah kamu makan harta diantara kamu dengan jalan yang batil, dan (janganlah) kamu menyuap dengan harta itu kepada para hakim, dengan maksud agar kamu dapat memakan sebagian harta orang lain itu dengan jalan dosa, padahal kamu mengetahui”.

Dan pada Q.S Al Maidah ayat 38 yang artinya "Laki-laki yang mencuru dan perempuan yang mencuri, potonglah tangan keduanya (sebagai) pembalasan bagi apa yang mereka kerjakan dan sebagai siksaan dari Allah. Dan Allah maha perkasa lagi maha bijaksana".

Dari kedua ayat tersebut di jelaskan bahwa, Allah mengharamkan bagi orangorang yang beriman untuk memanfaatkan, memakan dan menggunakan harta orang lain tanpa seizin pemiliknya, sama halnya mencuri. Dengan demikian, Segala sesuatu yang menimbulkan kerugian bagi pencipta pada hakikatnya dilarang

Majelis ulama' indonesia menetapkan fatwanya Nomor 1/MUNAS VII/MUI/15/2005 tentang Perlindungan Hak Kekayaan Intelektual (HAKI), yang di 
TAHKIM, Jurnal Peradaban dan Hukum Islam. Vol.2 No.2 (0ktober, 2019) | ISSN : 2597-7962

dalamnya meliputi Hak Perlindungan Varietas Tanaman, Hak Rahasia Dagang, Hak Desain Industri, Hak Desain Tata Letak Terpadu, Paten, Hak Atas Merek dan Hak Cipta. Dengan ketentuan hukum bahwa, suatu hak yang mendapat perlindungan hukum tidak bertentangan dengan hukum islam, mengandug unsur akad baik akad mu'awadhah maupun akad tabarru'at, dapat di wariskan dan di waqafkan.

Dalam Undang-undang hak cipta No. 19 Tahun 2002 perubahana atas UHC Tahun 1982, jangka waktu kepemilikan hak cipta ialah seumur hidup dan di tambah 50 tahun setelah meninggal, lebih dari itu suatu karya ciptaan akan menjadi milik umum, dengan kata lain, boleh memperbanyak tanpa harus izin kepada pencipta atah penerima hak cipta. Oleh karena itu, suatu karya cipta dapat di wariskan dan di waqafkan.

\section{B. PEMBAHASAN}

\section{Pengertian Hak Cipta}

Secara bahasa Hak cipta terbentuk dari dua kata yaitu Hak dan Cipta, hak berarti kekuasaan untuk berbuat sesuatu karena telah ditentukan Undang-undang, sedangkan kata cipta menyangkut daya kesanggupan batin (pikiran) untuk mengadakan sesuatu yang baru, terutama di lapangan kesenian ${ }^{1}$.

Menurut Konvensi Bern, yang dimaksud hak cipta ialah hak yang melindungi pencipta secara efektif atas hasil karyanya yang berupa karya satra dan seni².

Dalam bahasa Arab, hak cipta dikenal dengan istilah Haq Ibtikar. Secara etimologi, Ibtikar bermakna sesuatu yang awal (pertama), yang mengawali sesuatu sebelumnya, atau bisa diartikan juga dengan pagi-pagi ${ }^{3}$. Menurut terminologi $\mathrm{Haq} \mathrm{Al}$ Ibtikar adalah "Hak istimewa atas suatu ciptaan yang pertama kali diciptakan". Pengertian ini tidak jauh berbeda dengan pengertian dari segi etimologi. Fathi AlDuraini mendefinisikannya dengan "Gambaran pemikiran yang dihasilkan seorang

\footnotetext{
${ }^{1}$ Tim Penyusun. Kamus Besar Bahasa Indonesia, (Jakarta: Balai Pustaka, 1988).

${ }^{2}$ Harsono Adisumarto, Hak Milik Intelektual Khususnya Hak Cipta, (Jakarta: Akademika Pressindo, 1990), hlm. 44.

${ }^{3}$ Muhammad Syamsu Al-Haq Al-'Adzim Abadi, 'Aun Al-Ma'bud Syarah Sunan Abu Dawud Juz VII, Beirut : Dar Al-Kutub Ilmiyah, 1415 H, hlm. 170
} 
TAHKIM, Jurnal Peradaban dan Hukum Islam. Vol.2 No.2 (0ktober, 2019) | ISSN : 2597-7962

ilmuwan melalui pemikiran dan analisanya, hasilnya merupakan penemuan atau kreasi pertama yang belum dikemukakan ilmuwan sebelumnya." 4

Disebutkan dalam Undang-undang No. 28 tahun 2014 tentang Hak Cipta, bahwsanya yang dimaksud dengan hak cipta ialah: "Hak cipta adalah hak eksklusif pencipta yang timbul secara otomatis berdasarkan prinsip deklaratif setelah suatu ciptaan diwujudkan dalam bentuk nyata tanpa mengurangi pembatasan sesuai dengan ketentuan peraturan perundang-undangan ${ }^{5} "$.

Pengertian Hak Cipta yang diatur dalam UUHC (Undang-undang Hak Cipta) tersebut memberikan simpulan bahwa hak cipta merupakan hak ekslusif atau khusus bagi pencipta suatu karya intelektual untuk menggunakan, mengumumkan atau sekaligus juga untuk memperbanyak ciptaannya. Pencipta atau pemegang hak juga dapat memberikan izin kepada siapa saja baik perorangan atau usaha tertentu untuk menggunakan karyanya. Hak cipta mengenal dua jenis hak yang terkandung dalam suatu ciptaan, yaitu hak cipta (Copy Rights) dan Hak terkait (Neighboring Rights). Kedua hak ini merupakan hak ekslusif yang bersifat eksklusif insdustrialis bagi pemilik suatu $\operatorname{ciptaan}^{6}$

\section{Prinsip-prinsip Hak Cipta}

Hak cipta merupakan salah satu dari 7 cabang HKI (Hak Kekayaan Intelektual $^{7}$ maka prinsip-prinsip yang diterapkan pun sama dengan yang diterapkan dalam prinsip-prinsip HKI.

Adapun prinsip-prinsip HKI yang juga diterapkan menjadi prinsip-prinsip hak cipta adalah:

a. Prinsip Ekonomi

Dalam prinsip ekonomi, hak intelektual berasal dari kegiatan kreatif dari daya pikir manusia yang memiliki manfaat serta nilai ekonomi yang akan memberi keuntungan kepada pemilik hak cipta.

b. Prinsip Keadilan

${ }^{4}$ Fathi Al-Durainy, Al-Fiqh Al-Islamy AlMuqaran Ma'a Al-Madzahib, (Damaskus : Maktabah Thurbin, 1980), hlm. 223

${ }^{5}$ Pasal 1 ayat (1) Undang-undang No. 28 tahun 2014 tentang Hak Cipta

${ }^{6}$ Elyta Ras Ginting, Hukum Hak Cipta Indonesia Analisis Teori dan Praktik, (Bandung: Citra Aditya Bakti, 2012), hlm. 61

${ }^{7}$ Tomi Suryo Utomo, Hak Kekayaan Intelektual (KHI) di Era Global: Sebuah Kajian Kontemporer, (Yogyakarta:Graha Ilmu, 2009), hlm. 8 
TAHKIM, Jurnal Peradaban dan Hukum Islam. Vol.2 No.2 (0ktober, 2019) | ISSN : $2597-7962$

Prinsip keadilan merupakan suatu perlindungan hukum bagi pemilik suatu hasil dari kemampuan intelektual, sehingga memiliki kekuasaan dalam penggunaan hak atas kekayaan intelektual terhadap karyanya.

c. Prinsip Kebudayaan

Prinsip kebudayaan merupakan pengembangan dari ilmu pengetahuan, sastra dan seni guna meningkatkan taraf kehidupan serta akan memberikan keuntungan bagi masyarakat, bangsa dan Negara.

d. Prinsip Sosial

Prinsip sosial mengatur kepentingan manusia sebagai warga Negara, sehingga hak yang telah diberikan hukum atas suatu karya merupakan suatu kesatuan yang diberikan perlindungan berdasarkan keseimbanggan antara kepentingan individu dam Masyarakat /lingkungan.

\section{Dasar Hukum Hak Cipta di Indonesia}

Pada mulanya hak cipta diatur menurut Auteurswet Staatsblad 1912 Nomor 600, kemudian diubah dan diganti dengan Undang Undang Nomor 6 Tahun 1982 tentang Hak Cipta (Lembaran Negara RI Tahun 1982 Nomor 15, Tambahan Lembaran Negara RI Nomor 3217), yang disahkan dan diundangkan di Jakarta pada tanggal 12 April 1982, kemudian diubah dengan Undang Undang Nomor 7 Tahun 1987 (Lembaran Negara RI Tahun 1987 Nomor 42, Tambahan Lembaran Negara RI Nomor 3362), disahkan dan diundangkan di jakarta pada tanggal 19 September 1987, yang diubah lagi dengan Undang Undang Nomor 12 Tahun 1997 Tentang Hak Cipta (Lembaran Negara RI Tahun 1997 Nomor 29, Tambahan Lembaran Negara RI Nomor 2679), disahkan dan diundangkan di jakarta pada tanggal 29 Juli 2002, selanjutnya disebut Undang-Undang Nomor 19 Tahun 2002 dan dirubah oleh Undang Undang No 28 Tahun 2014.

Secara yuridis formal, Indonesia diperkenalkan dengan masalah Hak Cipta pada Tahun 1912, yaitu pada saat diundangkannya Auteurswet (Wet Van 23 September 1912, Staatsblad 1912 Nomor 600), yang mulai berlaku sejak tanggal 23 September 1912. Meskipun pada waktu itu Indonesia telah memberlakukan Auteurswet 1912 tersebut $^{8}$.

\footnotetext{
${ }^{8}$ Eddy Damian, Hukum Hak CIpta, (Bandung: PT. Alumni, 2005), hlm. 137.
} 
TAHKIM, Jurnal Peradaban dan Hukum Islam. Vol.2 No.2 (0ktober, 2019) | ISSN : 2597-7962

\section{Konsep Hak Cipta Dalam Islam}

Secara umum permasalahan hak cipta dalam dunia Islam tidak dikenal pada awa-lawal pertumbuhan Islam, terutama berkaitan dengan hak ekonomi yang ada padanya, namun jika dilihat dari segi moral dan tanggung jawab ilmiah serta penghargaan kepada penulis maka umat Islam telah sepakat mengenai masru'nya menuliskan nama penulis di setiap karangan/tulisan ${ }^{9}$. Islam telah memberikan kaidahkaidah umum yang memberikan dasar hukum bagi kepemilikan kekayaan seorang penulis. Hal ini seperti pendapat dari Ibnu Hazm yang menyebutkan "Upah mengajar alQur'an, mengajar ilmu dengan cara bulanan dan dalam jumlah tertentu, jampi-jampi dengan al-Qur'an, menyalin Al-Qur'an atau buku-buku pelajaran semuanya dibolehkan ${ }^{10}$. Abu Hamid Al-Ghazali menceritakan, bahwa Imam Ahmad pernah ditanya tentang orang yang salah satu kertas catatannya terjatuh di jalan. Dalam kertas tersebut terdapat beberapa hadits atau catatan ilmiah misalnya. Apakah orang yang menemukan kertas tersebut diperbolehkan untuk mencatat isi kertas tersebut, baru kemudian mengembalikannya kepada pemiliknya? Jawaban Imam Ahmad, "Tidak boleh, dia harus minta izin terlebih dahulu."

Dalam sebuah hak cipta terkandung di dalamnya hak ekonomi (haq aliqtishadi) dan hak moral (haq al-adabi). Mengenai hak ekonomi maka setiap pembuat karya cipta berhak untuk mendapatkan materi dari karya ciptanya tersebut. Hal ini seperti definisi yang disebutkan oleh Abdullah Al-Mushlih dan Shalah Al-Shawi yang menyebutkan: Hak cipta adalah sejumlah keistimewaan yang dimiliki oleh seorang penulis/pengarang yang bisa dihargai dengan uang, terkadang hak ini disebut juga hak abstrak, hak kepemilikan seni/sastra atau hak-hak intelektualitas, hak ini juga berarti harga komersial dari tulisan atau karangannya, harga tersebut dibatasi oleh mutu dan keuntungan komersial yang bisa direalisasikan dengan menerbitkan hasil tulisan tersebut dan mengkomersilkannya". ${ }^{11}$ Adanya hak ekonomi ini menunjukan bahwa setiap pencipta memiliki kekuasaan penuh atas ciptaannya, sehingga ia mempunyai hak untuk mendapatkan manfaat baik materi ataupun moril dari karya ciptanya tersebut.

\footnotetext{
${ }^{9}$ Muhammad Amin Suma, Pengantar Tafsir Ahkam, (Jakarta: Raja Grafindo Persada, 2001), hlm. 146.

${ }^{10}$ Ibnu Hazm, Al-Muhalla Juz IX, Maktabah Syamilah, hlm. 193-194

${ }^{11}$ Abdullah Al-Muslih dan Shalah Al-Shawi, Fikih Ekonomi Keuangan Islam, (Jakarta: Daarul Haq, 2004), hlm. 319
} 
TAHKIM, Jurnal Peradaban dan Hukum Islam. Vol.2 No.2 (0ktober, 2019) | ISSN : 2597-7962

Dalam Islam selain hak ekonomi ada hak moral yang menjadi tanggung jawab setiap pembuat karya cipta, pencipta memiliki hak untuk disebutkan namanya ketika ciptaannya dikutip. Hal ini telah lama menjadi salah satu dari keilmiahan dalam Islam, bahkan ia merupakan salah satu dari keberkahan ilmu, sebagaimana disebutkan oleh Imam Al-Qurthuby dalam muqadimah tafsirnya. ${ }^{12}$

Sebagai sebuah hak baru dalam ruang lingkup hak kepemilikan, hak cipta tidak termaktub secara tekstual baik dalam AlQur'an maupun Al-Sunnah. Hanya saja keduanya memberikan dasar-dasar bagi permasalahan ini. Lalu apa dan bagaimana eksistensi hak cipta dalam Islam? Kenapa sebagian cendekiawan muslim memasukannya ke dalam hak kebendaan?

Hak cipta sebagai salah satu dari bentuk kepemilikan pribadi (milkiyah alfardhiyah) di dasarkan pada dalil-dalil yang menunjukan bahwa ia adalah bagian dari kepemilikan atas suatu benda. Karena setiap pembuat karya cipta mempunyai hak khusus atas ciptaannya. Hak atas hasil dari sebuah pekerjaan adalah hak milik dari orang yang bekerja tersebut. Jika dikaitkan dengan sebab-sebab tetapnya sebuah hak, maka hak cipta ada disebabkan adanya kerja dan kesungguhan seorang pencipta dalam membuat sebuah karya cipta. Inilah sebab adanya hak kepemilikan bagi seseorang. ${ }^{13} \mathrm{Di}$ dalam Al-Qur'an Surat AlNisaa ayat 32 disebutkan :

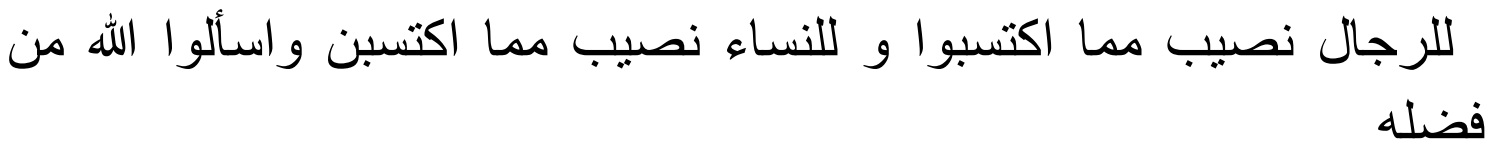

(Karena) bagi orang laki-laki ada bahagian daripada apa yang mereka usahakan, dan bagi para wanita (pun) ada bahagian dari apa yang mereka usahakan, dan mohonlah kepada Allah sebagian dari karunia-Nya.

Hak cipta dimasukan ke dalam hakhak kebendaan karena hak ini berkaitan dengan harta (karya cipta) yang berbentuk kewenangan terhadap suatu benda tertentu. Selain itu, hak ini juga melekat pada benda sebagai media penuangannya, misalnya

\footnotetext{
${ }^{12}$ Muhammad bin Ahmad bin Abu Bakr AlQurthuby, Jami' Li Ahkam Al-Qur'an, Juz I, (Beirut : Dar Al-Kutub Al'Araby, 1997), hlm. 27

${ }^{13}$ Luthfi Assyaukanie, Politik, HAM dan isuisu Teknologi dalam Fikih Kontemporer, Bandung : Pustaka Hidayah, tahun 1998, hlm. 30.
} 
TAHKIM, Jurnal Peradaban dan Hukum Islam. Vol.2 No.2 (0ktober, 2019) | ISSN : 2597-7962

buku. Seluruh ulama sepakat bahwa buku adalah termasuk harta yang dimiliki oleh seseorang, ia boleh menjualnya, menyewakannya atau menggadaikannya. ${ }^{14}$

Kemudian bagaimana dengan tindakan Indonesia sebagai Negara dengan mayoritas penduduk muslim terbanyak di dunia dalam menyikapi mengenai Hak Cipta ini? Pihak Majelis Ulama Indonesia pada Juli 2005 telah mengeluarkan fatwa dengan nomor : 1/MUNAS VII/MUI/5/2005 tentang perlindungan Hak Kekayaan Intelektual (HKI) yang terkandung di dalamnya hak cipta. ${ }^{15}$ Seluruh ulama umat Islam telah ijma' mengenai haramnya memakan harta orang lain dengan cara yang batil. ${ }^{16}$

\section{Sanksi Pelanggaran Terhadap Hak Cipta Menurut Hukum Positif Di Indonesia}

Undang-undang baru mengenai Hak Cipta mengatur tentang penyelesaian sengketa, antara lain melalui proses mediasi, arbitrase atau pengadilan serta penerapan delik aduan untuk tuntutan pidana ${ }^{17}$. Penyelesaian sengketa dalam undang-undang juga dinilai lebih tegas dan lebih jelas berikut sejumlah denda.

Umumnya pelanggaran hak cipta didorong untuk mencari keuntungan finansial secara cepat dengan mengabaikan kepentingan para pencipta dan pemegang izin hak cipta. Perbuatan para pelaku jelas melanggar fatsun hukum yang menentukan agar setiap orang dapat mematuhi, menghormati, dan menghargai hak-hak orang lain dalam hubungan keperdataan termasuk penemuan baru sebagai ciptaan orang lain yang diakui sebagai hak milik oleh ketentuan hukum.

Faktor-faktor yang mempengaruhi warga masyarakat untuk melanggar Hak Kekayaan Intelektual antara lain adalah ${ }^{18}$ :

a. Pelanggaran Hak Kekayaan Intelektual dilakukan untuk mengambil jalan pintas guna mendapatkan keuntungan yang sebesar-besarnya dari pelanggaran tersebut;

14 Bakr bin Abdullah Abu Zaid, Fiqh AnNawazil : Qadhaya Fiqhiyah Mu'ashirah. (Beirut : Muasasah Risalah, 1996). hlm. 173.

${ }^{15}$ Fatwa MUNAS VII Majelis Ulama Indonesia, Tahun 2005.

${ }^{16}$ QS. An-Nissa ayat 29

17 Akhmad Munawar dan Taufik Effendy, Upaya Penegakan Hukum Pelanggaran Hak Cipta Menurut Undang-Undang Nomor 28 Tahun 2014 Tentang Hak Cipta, “Al-'Adl”, Vol. 8 No. 2, MeiAgustus 2016, hlm. 129

${ }^{18}$ Ibid, hlm. 135 
TAHKIM, Jurnal Peradaban dan Hukum Islam. Vol.2 No.2 (0ktober, 2019) | ISSN : $2597-7962$

b. Para pelanggar menganggap bahwa sanksi hukum yang dijatuhkan oleh pengadilan selama ini terlalu ringan bahkan tidak ada tindakan preventif maupun represif yang dilakukan oleh para penegak hukum;

c. Ada sebagian warga masyarakat sebagai pencipta yang bangga apabila hasil karyanya ditiru oleh orang lain, namun hal ini sudah mulai hilang berkat adanya peningkatan kesadaran hukum terhadap Hak Kekayaan Intelektual;

d. Dengan melakukan pelanggaran, pajak atas produk hasil pelanggaran tersebut tidak perlu dibayar kepada pemerintah; dan

e. Masyarakat tidak memperhatikan apakah barang yang dibeli tersebut asli atau palsu, yang penting bagi mereka harganya murah dan tertjangkau dengan kemampuan ekonomi

Berikut ketentuan sanksi pidana terhadap pelanggaran hak cipta yang sudah termaktub jelas dalam Undang-Undang No. 28 Tahun 2014 tentang Hak Cipta

\section{BAB XVII KETENTUAN PIDANA ${ }^{19}$ \\ Pasal 112}

Setiap Orang yang dengan tanpa hak melakukan perbuatan sebagaimana dimaksud dalam Pasal 7 ayat (3) dan/atau Pasal 52 untuk Penggunaan Secara Komersial, dipidana dengan pidana penjara paling lama 2 (dua) tahun dan/atau pidana denda paling banyak Rp300.000.000,00 (tiga ratus juta rupiah).

\section{Pasal 113}

(1) Setiap Orang yang dengan tanpa hak melakukan pelanggaran hak ekonomi sebagaimana dimaksud dalam Pasal 9 ayat (1) huruf i untuk Penggunaan Secara Komersial dipidana dengan pidana penjara paling lama 1 (satu) tahun dan/atau pidana denda paling banyak Rp100.000.000 (seratus juta rupiah).

(2) Setiap Orang yang dengan tanpa hak dan/atau tanpa izin Pencipta atau pemegang Hak Cipta melakukan pelanggaran hak ekonomi Pencipta sebagaimana dimaksud dalam Pasal 9 ayat (1) huruf c, huruf d, huruf f, dan/atau huruf h untuk Penggunaan Secara Komersial dipidana dengan pidana penjara paling lama 3

\footnotetext{
${ }^{19}$ Undang-undang No. 28 Tahun 2014 tentang Hak Cipta
} 
TAHKIM, Jurnal Peradaban dan Hukum Islam. Vol.2 No.2 (0ktober, 2019) | ISSN : 2597-7962

(tiga) tahun dan/atau pidana denda paling banyak Rp500.000.000,00 (lima ratus juta rupiah).

(3) Setiap Orang yang dengan tanpa hak dan/atau tanpa izin Pencipta atau pemegang Hak Cipta melakukan pelanggaran hak ekonomi Pencipta sebagaimana dimaksud dalam Pasal 9 ayat (1) huruf a, huruf $b$, huruf e, dan/atau huruf $g$ untuk Penggunaan Secara Komersial dipidana dengan pidana penjara paling lama 4 (empat) tahun dan/atau pidana denda paling banyak Rp1.000.000.000,00 (satu miliar rupiah).

(4) Setiap Orang yang memenuhi unsur sebagaimana dimaksud pada ayat (3) yang dilakukan dalam bentuk pembajakan, dipidana dengan pidana penjara paling lama 10 (sepuluh) tahun dan/atau pidana denda paling banyak Rp4.000.000.000,00 (empat miliar rupiah).

\section{Pasal 114}

Setiap Orang yang mengelola tempat perdagangan dalam segala bentuknya yang dengan sengaja dan mengetahui membiarkan penjualan dan/atau penggandaan barang hasil pelanggaran Hak Cipta dan/atau Hak Terkait di tempat perdagangan yang dikelolanya sebagaimana dimaksud dalam Pasal 10, dipidana dengan pidana denda paling banyak Rp100.000.000,00 (seratus juta rupiah).

\section{Pasal 115}

Setiap Orang yang tanpa persetujuan dari orang yang dipotret atau ahli warisnya melakukan Penggunaan Secara Komersial, Penggandaan, Pengumuman, Pendistribusian, atau Komunikasi atas Potret sebagaimana dimaksud dalam Pasal 12 untuk kepentingan reklame atau periklanan untuk Penggunaan Secara Komersial baik dalam media elektonik maupun non elektronik, dipidana dengan pidana denda paling banyak Rp500.000.000,00 (lima ratus juta rupiah).

\section{Pasal 116}

(1) Setiap Orang yang dengan tanpa hak melakukan pelanggaran hak ekonomi sebagaimana dimaksud dalam Pasal 23 ayat (2) huruf e untuk Penggunaan Secara Komersial dipidana dengan pidana penjara paling lama 1 (satu) tahun dan/atau pidana denda paling banyak Rp100.000.000 (seratus juta rupiah). 
TAHKIM, Jurnal Peradaban dan Hukum Islam. Vol.2 No.2 (0ktober, 2019) | ISSN : $2597-7962$

(2) Setiap Orang yang dengan tanpa hak melakukan pelanggaran hak ekonomi sebagaimana dimaksud dalam Pasal 23 ayat (2) huruf a, huruf b, dan/atau huruf f, untuk Penggunaan Secara Komersial dipidana dengan pidana penjara paling lama 3 (tiga) tahun dan/atau pidana denda paling banyak Rp500.000.000,00 (lima ratus juta rupiah).

(3) Setiap Orang yang dengan tanpa hak melakukan pelanggaran hak ekonomi sebagaimana dimaksud dalam Pasal 23 ayat (2) huruf c, dan/atau huruf d untuk Penggunaan Secara Komersial dipidana dengan pidana penjara paling lama 4 (empat) tahun dan/atau pidana denda paling banyak Rp 1.000.000.000,00 (satu miliar rupiah).

(4) Setiap Orang yang memenuhi unsur sebagaimana dimaksud pada ayat (3) yang dilakukan dalam bentuk Pembajakan dipidana dengan pidana penjara paling lama 10 (sepuluh) tahun dan/atau pidana denda paling banyak Rp4.000.000.000,00 (empat miliar rupiah).

\section{Pasal 117}

(1) Setiap Orang yang dengan sengaja dan tanpa hak melakukan pelanggaran hak ekonomi sebagaimana dimaksud dalam Pasal 24 ayat (2) huruf c untuk Penggunaan Secara Komersial dipidana dengan pidana penjara paling lama 1 (satu) tahun dan/atau pidana denda paling banyak Rp100.000.000 (seratus juta rupiah).

(2) Setiap Orang yang dengan sengaja dan tanpa hak melakukan pelanggaran hak ekonomi sebagaimana dimaksud dalam pasal 24 ayat (2) huruf a, huruf b, dan/atau huruf d untuk Penggunaan Secara Komersial, dipidana dengan pidana penjara paling lama 4 (empat) tahun dan/atau pidana denda paling banyak Rp1.000.000.000,00 (satu miliar rupiah).

(3) Setiap Orang yang memenuhi unsur sebagaimana dimaksud pada ayat (2) yang dilakukan dalam bentuk Pembajakan dipidana dengan pidana penjara paling lama 10 (sepuluh) tahun dan/atau pidana denda paling banyak Rp4.000.000.000,00 (empat miliar rupiah).

\section{Pasal 118}


TAHKIM, Jurnal Peradaban dan Hukum Islam. Vol.2 No.2 (0ktober, 2019) | ISSN : $2597-7962$

(1) Setiap Orang yang dengan sengaja dan tanpa hak melakukan pelanggaran hak ekonomi sebagaimana dimaksud dalam Pasal 25 ayat (2) huruf a, huruf b, huruf c, dan/atau huruf d untuk Penggunaan Secara Komersial, dipidana dengan pidana penjara paling lama 4 (empat) tahun dan/atau pidana denda paling banyak Rp1.000.000.000,00 (satu miliar rupiah).

(2) Setiap Orang yang memenuhi unsur sebagaimana dimaksud dalam Pasal 25 ayat (2) huruf d yang dilakukan dengan maksud Pembajakan dipidana dengan pidana penjara paling lama 10 (sepuluh) tahun dan/atau pidana denda paling banyak Rp4.000.000.000,00 (empat miliar rupiah).

\section{Pasal 119}

Setiap Lembaga Manajemen Kolektif yang tidak memiliki izin operasional dari Menteri sebagaimana dimaksud dalam Pasal 88 ayat (3) dan melakukan kegiatan penarikan Royalti dipidana dengan pidana penjara paling lama 4 (empat) tahun dan/atau pidana denda paling banyak Rp1.000.000.000,00 (satu miliar rupiah).

\section{Pasal 120}

Tindak pidana sebagaimana dimaksud dalam Undang-Undang ini merupakan delik aduan

\section{Sanksi Pelanggaran Terhadap Hak Cipta Menurut Hukum Pidana Islam}

Telah disebutkan pada penjelasan sebelumnya bahwa Hak Cipta merupakan sebuah hak yang baru dalam dunia Islam dan bisa dikatakan kontemporer, mengingat zaman dahulu belum ada pengaturan khusus yang berkenaan dengan hak cipta ini terutama dari segi hak ekonomi nya, sehingga kita tidak dapat menemukan nash AlQuran ataupun Hadits yang secara jelas membahas mengenai hak cipta ini.

Namun jika dikaitkan dengan pembahasan sebelumnya, bahwasanya dalam Hak Cipta terdapat dua hak penting yang terkandung didalamnya yaitu hak ekonomi dan hak moral. Dimana dijelaskan sebelumnya bahwa hak ekonomi ini menyangkut hak materi yang didapatkan oleh sang pencipta dimana ia mempunyai hak untuk mendapatkan manfaat baik materi ataupun moril dari karya ciptanya tersebut.

Dijelaskan juga bahwasanya hak cipta termasuk kedalam kategori hak kepemilikan karena setiap pembuat karya cipta mempunyai hak khusus atas ciptaannya. 
TAHKIM, Jurnal Peradaban dan Hukum Islam. Vol.2 No.2 (0ktober, 2019) | ISSN : $2597-7962$

Hak atas hasil dari sebuah pekerjaan adalah hak milik dari orang yang bekerja tersebut. Jika dikaitkan dengan sebab-sebab tetapnya sebuah hak, maka hak cipta ada disebabkan adanya kerja dan kesungguhan seorang pencipta dalam membuat sebuah karya cipta.

Dua hal ini yaitu hak Ekonomi dan hak Kepemilikan, jika digabungkan dapat menjadi suatu kesatuan yang memiliki kekuatan hukum khususnya dalam pidana Islam. Sehingga kita dapat menerapkan metode qiyas dimana kita mencari hukum syara' yang sudah ada yang mempunyai kesamaan dalam hak ekonomi dan kepemilikan agar hukumnya bisa diterapkan juga dalam perkara pelanggaran Hak Cipta.

Dan jika ditelaah, pelanggaran terhadap hak cipta bisa dikatakan juga dengan pelanggaran terhadap hak milik orang lain yang menyebabkan suatu kerugian materil maupun non-materil terhadap si pencipta karena adanya pengambil alihan kekuasaan secara sembunyi-sembunyi. Jika dikaitkan hal ini mirip dengan unsur pokok jarimah pencurian dalam pidana Islam, seperti uraian berikut ini:

a. Barang yang diambil berupa harta ${ }^{20}$. Tentu hal ini sesuai dengan penjelasan sebelumnya bahwa hak cipta merupakan harta karena mengandung hak ekonomi yang dapat memberikan manfaat kepada si pencipta secara materil.

b. Harta yang diambil milik orang lain ${ }^{21}$. Hal ini sejalan karena disebutkan juga sebelumnya bahwa hak cipta merupakan atau termasuk kedalam hak milik bagi siapa yang menciptakannya, maka jika kebermanfaatannya berpindah tangan maka bisa dipastikan hak cipta telah diambil oleh pihak lain.

c. Melawan hukum ${ }^{22}$, jelas dalam hai ini keduanya mengandung unsur sama-sama melawan hukum. Karena sudah sangat jelas Al-Quran melarang adanya pencurian, seperti disebutkan dalam surat Al-Maidah ayat 38 yang berarti: lakilaki yang mencuri dan wanita yang mencuri, potonglah kedua tangannya (sebagai) pembalasan bagi apa yang mereka kerjakan dan sebagai siksaan dari Allah. Allah maha perkasa lagi bijaksana”

Sudah jelas bahwa kegiatan pelanggaran terhadap hak cipta merupakan bagian dari pencurian, maka sanksinya pun sama dengan sanksi bagi orang yang melakukan pencurian. Meskipun dalam hukum Pidana Islam disebutkan bahwa hukuman bagi

\footnotetext{
${ }^{20}$ M. Nurul Irfan, Hukum Pidana Islam, (Jakarta: Amzah, 2016), hlm. 85

${ }^{21}$ Ibid

${ }^{22}$ Ibid
} 
TAHKIM, Jurnal Peradaban dan Hukum Islam. Vol.2 No.2 (0ktober, 2019) | ISSN : 2597-7962

orang yang mencuri adalah hukuman potong tangan, namun ternyata hukuman ini hanya berlaku bagi Negara yang menerapkan hukum Islam sebagai dasar negaranya secara utuh, sementara bagi Indonesia yang menerapkan asas Pancasila, sanksi bisa disesuaikan dengan yang sudah diterangkan dalam KUHPidana ${ }^{23}$.

Hak cipta dalam pandangan Islam adalah hak kekayaan yang harus mendapat perlindungan hukum sebagaimana perlindungan hukum terhadap harta milik seseorang. ${ }^{24}$ Kalangan ulama kontemporer bersepakat bahwa hak-hak cipta itu menurut syariat terpelihara. Para pemiliknya bebas memperlakukan hak cipta itu sekehendak mereka. Tak seorangpun yang berhak melanggarnya, namun dengan syarat, jangan sampai dalam karya-karya tulis itu ada yang melanggar syariat Islam yang lurus. Itulah yang menjadi keputusan akhir dari lembaga pengkajian fikih Islam yang lahir dari organisasi konferensi Islam pada pertengahan kelima di Kuwait tahun 1409 H, bertepatan dengan tahun 1988 M. ${ }^{25}$ Islam melarang terhadap perbuatan pencurian yang dalam hal ini bisa dicontohkan seperti praktik pembajakan dan penggandaan karya tulis yang sering terjadi di Indonesia. Perbuatan itu jelas merupakan tindakan pidana menurut hukum Islam. ${ }^{26}$

\section{SIMPULAN}

Kesimpulan dari penelitian ini adalah sebagai berikut:

1. Hak cipta merupakan hak ekslusif atau khusus bagi pencipta suatu karya intelektual untuk menggunakan, mengumumkan atau sekaligus juga untuk memperbanyak ciptaannya. Pencipta atau pemegang hak juga dapat memberikan izin kepada siapa saja baik perorangan atau usaha tertentu untuk menggunakan karyanya.

2. Adapun prinsip-prinsip HKI yang juga diterapkan menjadi prinsip-prinsip hak cipta adalah: Prinsip Ekonomi, Prinsip Keadilan, Prinsip Kebudayaan dan Prinsip Sosial.

23 Muhammad Djakfar, Hukum Bisnis Membangun Wacana Integrasi Perundangan Nasional dengan Syariah, (Malang: UIN Malang Press, 2009), hlm. 251-257

${ }^{24}$ Ibid, hlm. 257

${ }^{25}$ Abdullah Al-Muslih dan Shalah Al-Shawi, Fikih Ekonomi Keuangan Islam, hlm. 315

${ }^{26}$ Muhammad Djakfar, Hukum Bisnis Membangun..., hlm. 257 
TAHKIM, Jurnal Peradaban dan Hukum Islam. Vol.2 No.2 (0ktober, 2019) | ISSN : $2597-7962$

3. Hukum positif mengenai Hak cipta yang berlaku di Indonesia ialah UndangUndang Nomor 19 Tahun 2002 dan dirubah oleh Undang Undang No 28 Tahun 2014.

4. Dalam hukum Islam, Hak cipta termasuk kedalam hak kepemilikan yang mana didalamnya mengandung unsur hak ekonomi dan hak moril. Termasuk didalamnya Pihak Majelis Ulama Indonesia pada Juli 2005 telah mengeluarkan fatwa dengan nomor : 1/MUNAS VII/MUI/5/2005 tentang perlindungan Hak Kekayaan Intelektual (HKI) yang terkandung di dalamnya hak cipta. Seluruh ulama umat Islam telah ijma' mengenai haramnya memakan harta orang lain dengan cara yang batil.

5. Sanksi terhadap pelanggaran Hak Cipta pada hukum positif di Indonesia dijelaskan pada BAB XVII tentang ketentuan Pidana pasal 112 sampai pasal 120 pada Undang-Undang No. 28 tahun 2014.

6. Sedangkan Sanksi terhadap pelanggaran Hak Cipta menurut Hukum Pidana Islam sama kedudukannya dengan Jarimah pencurian, yaitu potong tangan bagi si pelanggar, namun karena Indonesia Negara yang berasaskan Pancasila, maka sanksi mengikuti hukum yang sudah tertera di KUHPidana. 
TAHKIM, Jurnal Peradaban dan Hukum Islam. Vol.2 No.2 (0ktober, 2019) | ISSN : 2597-7962

\section{DAFTAR PUSTAKA}

Abu Zaid, Bakr bin Abdullah. (1996). Fiqh AnNawazil : Qadhaya Fiqhiyah Mu'ashirah. Beirut : Muasasah Risalah.

Adisumarto, Harsono. (1990). Hak Milik Intelektual Khususnya Hak Cipta, Jakarta: Akademika Pressindo.

Al-'Adzim Abadi, Muhammad Syamsu Al-Haq. (1415 H), 'Aun Al-Ma'bud Syarah Sunan Abu Dawud Juz VII, Beirut : Dar Al-Kutub Ilmiyah.

Al-Durainy, Fathi. (1980). Al-Fiqh Al-Islamy AlMuqaran Ma'a Al-Madzahib, Damaskus : Maktabah Thurbin.

Al-Muslih, Abdullah dan Al-Shawi, Shalah. (2004). Fikih Ekonomi Keuangan Islam, Jakarta: Daarul Haq.

AlQurthuby, Muhammad bin Ahmad bin Abu Bakr. (1997). Jami' Li Ahkam Al-Qur'an, Juz I, Beirut : Dar Al-Kutub Al'Araby.

Assyaukanie, Luthfi. (1998). Politik, HAM dan isuisu Teknologi dalam Fikih Kontemporer, Bandung : Pustaka Hidayah.

Damian, Eddy. (2005). Hukum Hak CIpta, Bandung: PT. Alumni.

Djakfar, Muhammad. (2009). Hukum Bisnis Membangun Wacana Integrasi Perundangan Nasional dengan Syariah, Malang: UIN Malang Press.

Fatwa MUNAS VII Majelis Ulama Indonesia, Tahun 2005.

Ginting, Elyta Ras. (2012). Hukum Hak Cipta Indonesia Analisis Teori dan Praktik, Bandung: Citra Aditya Bakti.

Hazm, Ibnu . t.th. Al-Muhalla Juz IX, Maktabah Syamilah.

Irfan, M. Nurul. (2016). Hukum Pidana Islam, Jakarta: Amzah.

Tim Penyusun. (1988). Kamus Besar Bahasa Indonesia. Jakarta: Balai Pustaka. 
TAHKIM, Jurnal Peradaban dan Hukum Islam. Vol.2 No.2 (0ktober, 2019) | ISSN : $2597-7962$

Munawar, Akhmad dan Effendy, Taufik. Upaya Penegakan Hukum Pelanggaran Hak Cipta Menurut Undang-Undang Nomor 28 Tahun 2014 Tentang Hak Cipta, "Al‘Adl’, Vol. 8 No. 2, Mei-Agustus 2016.

Pasal 1 ayat (1) Undang-undang No. 28 tahun 2014 tentang Hak Cipta

Suma, Muhammad Amin. (2001). Pengantar Tafsir Ahkam, Jakarta: Raja Grafindo Persada.

Undang-undang No. 28 Tahun 2014 tentang Hak Cipta

Utomo, Tomi Suryo. (2009). Hak Kekayaan Intelektual (KHI) di Era Global: Sebuah Kajian Kontemporer, Yogyakarta. 
TAHKIM, Jurnal Peradaban dan Hukum Islam. Vol.2 No.2 (0ktober, 2019) | ISSN : 2597-7962 